\title{
PROJECT-BASED LEARNING TOOLS FOR LIGHT VEHICLE ENGINE MAINTENANCE SUBJECTS AT VOCATIONAL HIGH SCHOOL
}

\author{
Muslim $^{1 *}$, Ambiyar ${ }^{1}$, Dedi Setiawan' ${ }^{1}$, Rido Putra ${ }^{1}$ \\ ${ }^{1}$ Universitas Negeri Padang \\ Jl. Prof. Dr. Hamka, Kampus UNP Air Tawar, Padang 25132, Indonesia
}

\begin{abstract}
This study aims to develop learning tools for project-based light vehicle engine maintenance and describe the teacher's response to the application of project-based learning tools in light vehicle engine maintenance subjects. This research is a research and development $(R \& D)$ model with ADDIE. The ADDIE development model consists of analysis, design, development, implementation, and evaluation. The results showed that the product developed was valid in terms of validity, very practical in terms of practicality, and very high in the aspect of effectiveness. Based on the aspects of validity, it can be specified that the syllabus gets a percentage score of $90.25 \%, 88.78 \%$ learning implementation plan, $86.56 \%$ module, $88.93 \%$ job sheet, $87.5 \%$ achievement test instrument, and project test instrument $87.08 \%$. Based on aspects of practicality assessed from the teacher's response, it can be specified that the syllabus gets a percentage score of $88.67 \%, 86.88 \%$ learning implementation plan, $88.75 \%$ module, $88.77 \%$ job sheet, $85.42 \%$ test instrument for learning outcomes, and $83.33 \%$ project test instruments. Overall, teachers find it helpful to develop projectbased learning tools. Based on the effectiveness, the results of students' knowledge tests with the percentage of mastery learning in the knowledge area amounted to $86.67 \%$, and the skill area amounted to $86.67 \%$ with very high criteria. Researchers can conclude that project-based learning tools on light vehicle maintenance subjects are in accordance with valid, practical, and effective criteria.
\end{abstract}

Keywords: learning tools, project-based learning, ADDIE model, validity, teacher response

How to cite: Muslim, M., Ambiyar, A., Setiawan, D., \& Putra, R. (2020). Developing project-based learning tools for light vehicle engine maintenance subjects at vocational high school. Jurnal Pendidikan Vokasi, 10(1), 22-33. doi:https://doi.org/10.21831/jpv.v10i1.29564

*Corresponding Author:
Muslim muslim@ft.unp.ac.id

Department of Automotive Engineering, Faculty of Engineering, Universitas Negeri Padang Jl. Prof. Dr. Hamka, Kampus UNP Air Tawar, Padang 25132, Indonesia 


\section{INTRODUCTION}

The learning tools is a material that should be prepared by a teacher before implementing learning and one of the main things that must be available because it is one indicator of the success of the learning process so that teachers are more focused on providing material to students (Mauliana et al., 2018). Designing learning tools is important for a teacher because learning tools can be guidelines, benchmarks, increased professionalism, and teachers' ability to help facilitate learning. Learning tools can facilitate teachers and students in the learning process (Purnamasari \& Wangid, 2016). However, in reality, there are still a few teachers who can develop learning tools. The teacher only uses the existing learning tools without making them independently, so the learning process is still textual. The teacher only explains the material that is already in the textbook, and the students only listen and record the teacher's explanation, which results in more classroom activity dominated by the teacher.

Development of learning tools whose ultimate goal is to emphasize mastery of concepts and mastery of students' skills because learning tools are tools used to assist in learning both in the classroom and in the laboratory where they conduct practical work (Prasetyo, 2011). Learning tools that emphasize thinking skills must be developed and according to the context of student learning environments so that students have much better competence than before (Fatkhurrokhman et al., 2017). This learning tool is expected to be contextual, not only covering the cognitive domain but also psychomotor and affective and in accordance with the conditions of students who are undergoing the learning process.

The results of researchers' observations and interviews with several automotive productive teachers at SMKN 1 Lahat, especially in light vehicle engine maintenance subjects, showed that the lessons learned at school were less varied. Almost all learning materials for light vehicle engine maintenance are delivered using the lecture method. The teacher often gives lectures, and students listen to what is conveyed by the teacher. This makes not all students listen carefully; some are busy themselves, some are bored, less motivated, and do not listen to the teacher's explanation.

To develop learning tools for the maintenance of light vehicle engines in accordance with the 2013 curriculum, alternative actions that can be offered as expected are project-based learning. This project-based learning usually uses problems as the beginning of learning to be able to gather knowledge and materials because students are the focal point in the learning process (Mozas \& Barba-Colmenero, 2013). In other words, the development of project-based learning tools is a planned and ongoing effort for learning to maintain light engine vehicles that will be applied to light vehicle engineering students at SMKN 1 Lahat.

Project-based learning is designed to investigate students and understand when dealing with complex problems (Sailin \& Mahmor, 2018). So that learning objectives can be achieved well, where students become active learners, students can manage their own project completion activities or learning tasks so that the learning process can be more independent and can also provide indepth knowledge to students (Baghoussi \& El Ouchdi, 2019). The benefits of project-based learning, among others, are to gain new knowledge and skills for students during the learning process (Aydın et al., 2018). On the other hand, the emergence of ability and activeness in problem-solving and increasing understanding skills in managing information both independently and in groups are also the benefits of this problem-based learning. The emergence of student learning activities is also the result of teacher learning in providing learning so that students can think more actively in learning (Muslim et al., 2019). The characteristics of successful teachers are being able to provide learning that makes students compelled to solve problems (Arends, 2001). This is suitable for the subject of light vehicle engine maintenance. Based on the problems that have been explained, the researchers conducted research using the theme of developing project-based learning devices with the subject being the subject of light vehicle engine maintenance at SMKN 1 Lahat.

The tool used in the learning process is called learning tools (Prasetyo, 2011). Learning tools are a collection of learning resources that allow teachers and students to carry out learning activities. The success of a teacher in learning is desirable; to meet these objectives requires good preparation. Learning tools are also a number of materials or guidelines used in student learning processes (Suhadi, 2007). Learning tools must also be monitored so that the implementation of learning 
is more directed towards achieving the expected competence (Rusman, 2012). One of the learning tools that will be developed is the syllabus. This syllabus plays an important role in the application of other devices.

The term syllabus can be defined as "outline, summary, or subject matter". The syllabus refers to curriculum development products in the form of further elaboration of the standard competencies and basic abilities to be achieved by students, which result from the actions of a teacher in class, which are usually made in written form (Sabbah, 2018). The syllabus is also part of the curriculum, which contains a description of what the teacher will teach in class, about the goals to be achieved later on, and what skills students will get as recipients of learning (Hoesny, 2013). The syllabus is also used as a set of plans and arrangements regarding learning activities, classroom management, and learning outcomes assessment. This is made so that teachers can understand in whole or all components related to basic competencies in the learning process (Yulaelawati, 2004). With this syllabus, other instruments can be made by referring to and considering educational institutions in the learning process that need other important aspects, such as making learning plans, modules, job sheets, and so on.

The Learning Implementation Plan is a plan to describe the procedures and organize learning to achieve the basic competencies set out in the Content Standards and explained in the syllabus (Kunandar, 2013). The development of a learning implementation plan must consider several important aspects, for example, it must be based on the condition of the students to be taught. Then, in preparing the learning implementation plan, the syntax must adjust to the curriculum that applies to an educational institution. In preparing and developing a learning implementation plan, it is usually not separated from the scope of the subject matter that already exists in the syllabus. With this learning implementation plan, new teachers can adjust the modules' use or the modules that will be developed for the topic can be applied to students in the learning process.

Modules are usually one of the teacher's facilities to students in the learning process (Hamid et al., 2017). The module is one of the learning media that can be used to support teaching and learning activities, usually in the form of printed media (Serevina et al., 2018). The material or contents of the written module must be in accordance with the lesson plan. The module content includes the substance students need to master a competency by utilizing more efficient learning time (Martiningsih \& Susilowati, 2019). Modules must describe the basic competencies that students want to achieve, are presented using good language, are interesting, and are equipped with illustrations (Abdul, 2009). It is highly recommended that one competency be developed into one module, but considering the specific characteristics, breadth, and complexity of the competency, one competency may be developed into more than one module.

Job sheets are practical learning guides that have work drawings as material to practice and are accompanied by operational work steps and are equipped with evaluation sheets for student practice independently (Nurhasanah et al., 2017). The job sheet has the final goal of training students' abilities in practicum learning (Soivan \& Rijanto, 2018). Job sheets that are used by teachers to students in practical matters have a scope of material that must be in accordance with the syllabus used in institutional units (Jumargo et al., 2011). On the other hand, the job sheet is also a sheet containing the teacher's tasks when doing practical activities to students, and students must follow the work that is on the job sheet (Abdillah, 2013). Job sheet is used when doing practical work aimed at facilitating student work in accordance with instructions specified by the practical teacher, so students can focus more on learning (Widyastuti \& Utami, 2018). The benefits gained when using a job sheet during practical work are to better understand and do their job correctly according to the instructions contained in the job sheet. In addition to the developed worksheet, there are other things that must be considered, namely the assessment instruments. The teacher uses the instrument in assessment to collect information about students and improve the quality of learning because between the assessment and learning outcomes are interrelated with each other (Shofwanthoni et al., 2019).

Assessment instruments must be used and developed to gather student information and facilitate teachers in measuring or developing student character (Handoyo \& Listyarini, 2018), because the assessment instrument is one form of assessment consistent with the K-13 curriculum (Anjaya et al., 2019). Therefore, the assessment instruments developed in this study include knowl- 
edge and skills competency assessment instruments. Assessment is a bridge between the teacher and students in the learning process, so the assessment of knowledge and skills needs to be there (Wiliam, 2013). Knowledge competency assessment focuses on intellectual knowledge and abilities (Wahyuni et al., 2018). Knowledge competency assessment in this study uses written tests in the form of multiple choice. The competency assessment skills to be developed are project assessments. The instrument used refers to the achievement of learning outcomes indicators according to the scope of the curriculum that students can do. Project review aspects that need to be considered include management skills, relevance, and authenticity. Management ability is students' ability to choose topics, search for information, and manage project implementation time.

Project-based learning is the application of active learning methods carried out in studentcentered classrooms (Zancul et al., 2017). This learning will positively influence the wearer to improve student collaboration skills (Shin, 2018). In simple terms, project-based learning is defined as teaching that tries to connect technology, sources of information, and daily life problems that focus on student learning (Gerhana et al., 2017). The application of this learning will increase high-level thinking to solve the problems that have been given (Chiang \& Lee, 2016). During presentations, students show what they are learning as they travel through class units, interact with related subjects, collaborate with each other and with their teachers, and assess themselves and each other that usually produces a tangible product (Ismuwardani et al., 2019). The final outcome of this projectbased learning is in the form of project assignments with qualities that can later be accounted for (Harmer \& Stokes, 2014).

Project-based learning also uses projects /activities as the core of learning during the learning process (Syarif, 2016). This allows students to be more actively involved in learning (Damayanti et al., 2014). The application of this learning in the form of project assignments to improve student understanding of learning (Winatha \& Abubakar, 2018). Students will get the opportunity to overcome challenges and can help directly with discussion groups or communities in real life (Kricsfalusy et al., 2018). The teacher is only a facilitator, evaluating the products of student work displayed in the results of projects that have been carried out, so as to produce tangible products that can encourage student creativity to be able to think critically to analyze the material in the concept of the problem (Habók \& Nagy, 2016). It can be concluded that project-based learning is a learning model that is oriented to develop students' knowledge and learning skills through a series of planning activities, the learning process, and producing certain products framed in one single container project-based.

Teachers must pay attention to the most important things when using this learning model, one of which is that teachers should consider important components such as facilitators in the learning process (Trianto, 2014). These components include several things: (1) curriculum content, (2) the multimedia component, (3) the student manual component, (4) cooperation, (5) the component of the relationship with the real world, (6) time frame, and (7) assessment. The assessment process is carried out continuously in each lesson, such as assessing teachers, friends, and reflecting on oneself. To better understand project-based learning, it can be seen in Figure 1.

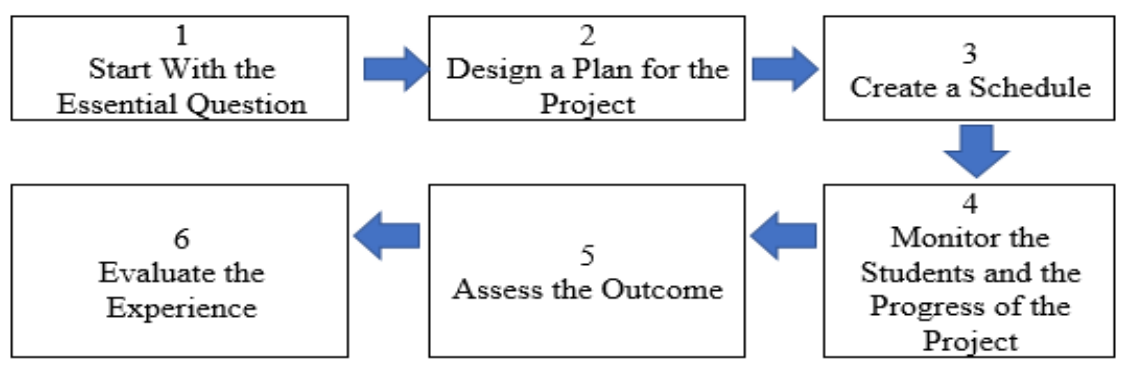

Figure 1. Project Based Learning Diagram (Syarif, 2016)

The project-based learning model always starts by discovering the basic questions, which will later be the basis for assigning project assignments to students (Wekesa \& Ongunya, 2016). The topic used must also be related to the real world. Furthermore, with the teacher's help, the 
student group will design activities to be carried out on each project (Febriana, 2017). The greater the involvement and ideas of students (groups of students) used in the project, the greater their sense of ownership of the project (Sari \& Mukhadis, 2017). Next, the teacher and students determine the time limit provided in completing the tasks (activities) of their project (Jaime et al., 2016). In the world of education, especially in SMKN 1 Lahat, subjects for maintenance of light vehicle engines must be taken by light vehicle engineering students. Maintenance of a light vehicle engine is one of the theoretical subjects that is then equipped with practical activities. Practicum materials have basic competencies, namely: maintenance of cooling systems, lubrication systems, ignition systems, and fuel systems. The material to be taken for testing and research is the ignition system material, namely the introduction of components and maintenance of the ignition system on a regular basis (periodic service).

\section{RESEARCH METHOD}

This research is a research and development that has the objective to obtain/find a particular product. Research and development $(\mathrm{R} \& \mathrm{D})$ is used to develop and validate products. The product results will be tested for practicality and effectiveness of the product so that it is suitable for use in the world of education. Researchers design learning tools that are developed by formulating learning objectives either developed in general or specifically. Then, the development of test items is used to measure the level of progress and achievement of students and pay attention to the principles of message design to attract readers' attention, especially students.

The model used is ADDIE (Dick et al., 2015). The ADDIE development model consists of (1) analysis in the sense of determining a problem and a solution for student competence in school, (2) design, which aims to determine the strategy and form of the device being developed, (3) development, which means developing the instrument under study, (4) implementation, which aims to apply the design of learning tools, and (5) evaluation, which aims to evaluate the learning tools developed (Sari, 2017). Figure 2 is shown to make the ADDIE model applied in this study clearer.

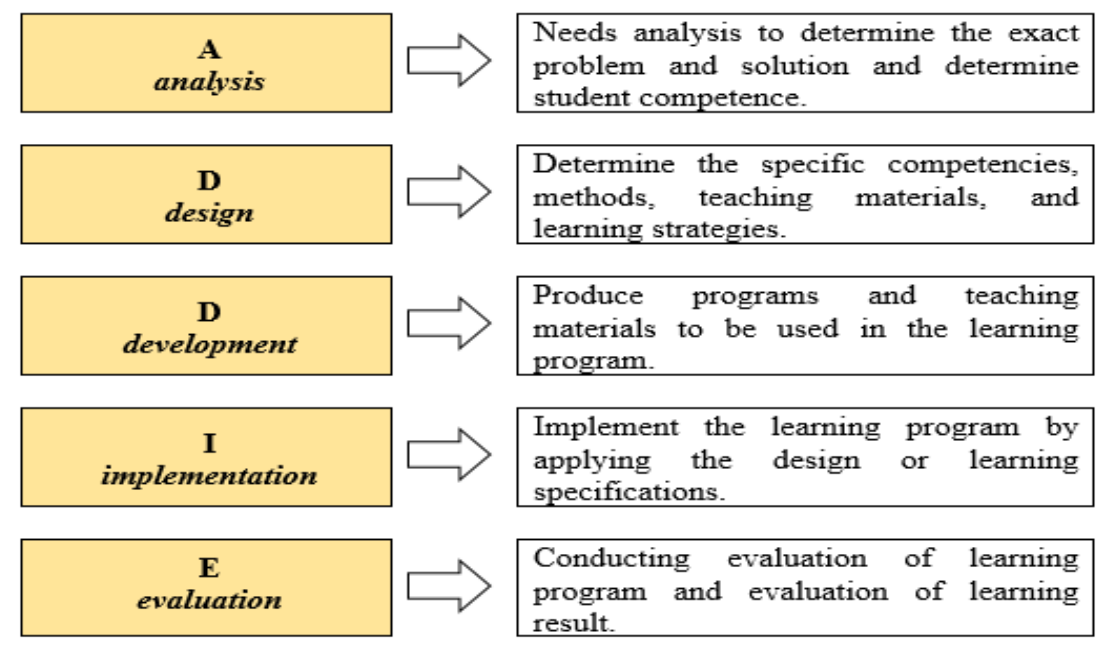

Figure 2. ADDIE Model Diagram (Sari, 2017)

The instrument used for validity is the Rating questionnaire-value analysis techniques using the Likert scale (Sugiyono, 2017). Product trial activities carried out after the learning device produced is said to be valid. Validators involved in the validation phase are two lecturers majoring in automotive engineering and three teachers in light vehicle engineering studies. The total validator is five people. Two expert lecturers and three teachers assessed the evaluation of syllabus validity, teacher response questionnaire, knowledge test instrument, and project test instrument. The evaluation of the lesson plan's validity, module, and job sheet is divided into two aspects, respectively. One lecturer and two teachers assessed the material aspect, while one lecturer and one teacher assessed the media aspect. 
A valid learning tool was tested on a limited trial at SMK 1 Lahat. A limited trial was conducted on 30 students. This activity is carried out to measure the practicality of the device being developed.

Practicality analysis is assessed based on the teacher's response to the device that has been developed. The analysis technique uses a Likert scale (Sugiyono, 2017). Learning devices are said to be practical if they can be used in the learning process of maintaining light vehicles in SMKN 1 Lahat.

The questionnaire in this study was generally used to assess learning devices that had been developed, which consisted of questionnaires on the validity of the syllabus, the validity of the learning plan, module validity, the validity of worksheets, and the validity of student learning outcomes tests. Simultaneously, the teacher's response questionnaire aims to determine the teacher's response to the learning device that was developed to obtain a level of practicality. To determine whether the student has been able to master the material carried out a test of learning outcomes for cognitive understanding and project tests for understanding skills in practice.

Analysis of effectiveness using the design of a one-shot case study (Sugiyono, 2017). The results of the study using a quantitative approach from the application of the developed device. Researchers treat without first testing. Researchers conducted a posttest with three limited trials (Sugiyono, 2017). Analysis of effectiveness is assessed from student learning outcomes tests. The learning outcomes test aims to obtain data about the mastery of the material provided after students take part in learning by using project-based learning tools carried out at the end of the experiment. The project test aims to obtain data about mastery of the material in the area of skills provided after students take part in learning by using project-based learning tools carried out at the end of the experiment.

\section{RESULTS AND DISCUSSION}

Mastery learning was evaluated using the one-shot case study method by conducting a posttest three times after being treated. The reference used to determine student learning completeness is to compare students' post-test average scores with the achievement of predetermined minimum completeness criteria. To be clearer about the post test scores results using the one-shot case study, see Table 1 and Figure 3.

Table 1. Average Post Test Score Using One-Shot Case Study

\begin{tabular}{cccc}
\hline Activities & n & Average & Standard Deviation \\
\hline Post Test 1 & & 74.56 & 6.34 \\
Post Test 2 & 30 & 78.22 & 6.17 \\
Post Test 3 & & 82.56 & 9.70 \\
\hline
\end{tabular}

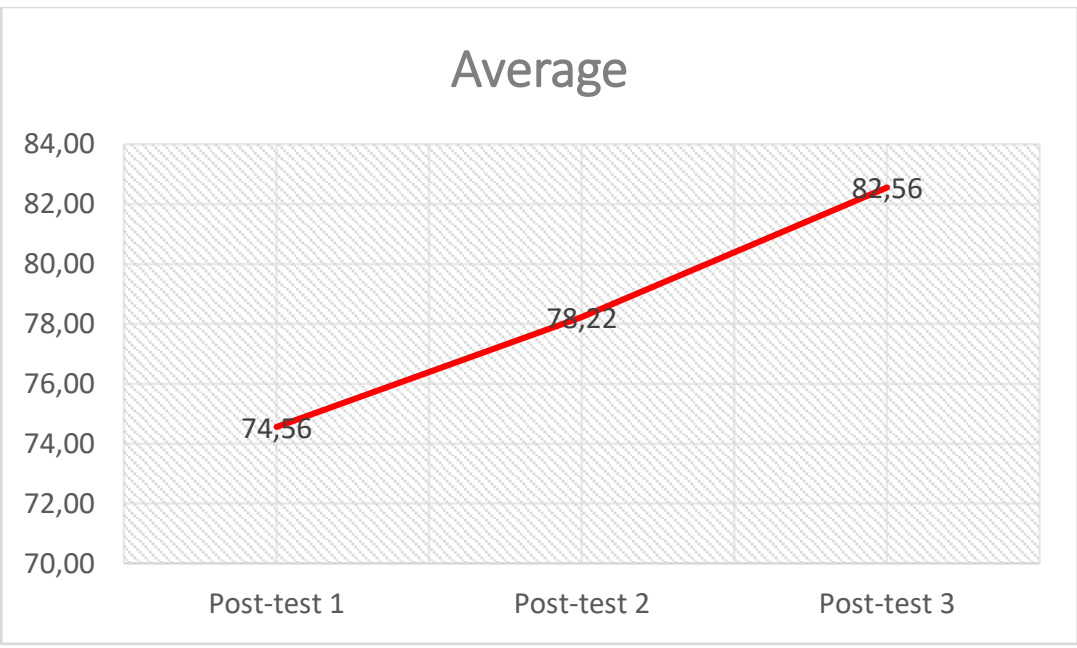

Figure 3. Results of One-Shot Case Study Diagram 
Based on Table 1 and Figure 3, it can be seen and understood that the average value of the post-test increased from post-test 1 to post-test 3 . To see the average post-test value in limited testing and the final results of the score student learning outcomes, see Table 2 and Table 3.

Table 2. Average Post-Test on Limited Testing

\begin{tabular}{cccccc}
\hline Activities & n & Average & SD & The value of t arithmetic & t-table \\
\hline Post-test 1 & 30 & 74.56 & 6.34 & \multirow{2}{*}{2.387} & \multirow{2}{*}{2.048} \\
Post-test 2 & 30 & 78.22 & 6.17 & & \multirow{2}{*}{2.048} \\
\hline Post-test 2 & 30 & 78.22 & 6.17 & \multirow{2}{*}{2.396} & \multirow{2}{*}{2.048} \\
Post-test 3 & 30 & 82.56 & 9.70 & \multirow{2}{*}{4.478} & \\
\hline Post-test 1 & 30 & 74.56 & 6.34 & 9.70 & \\
Post-test 3 & 30 & 82.56 & &
\end{tabular}

Table 3. Result of Student Tests Study Value Analysis

\begin{tabular}{cccccc}
\hline & n & Min value & Max value & Average & SD \\
\hline Student Knowledge Test & 30 & 56.67 & 93.33 & 82.56 & 9.70 \\
\hline
\end{tabular}

It can be concluded that the percentage of completeness of learning outcomes of light vehicle engineering in SMKN 1 Lahat in limited testing was $86.67 \%$ with very high criteria. From the results of the analysis of the student project test results, it is known that the average value of the project is 80.50 , with a percentage of limited testing of $86.67 \%$ in very high criteria. In order to know the analysis of student project test scores clearly, Table 4 is presented.

Table 4. Results of Test Analysis Project Value

\begin{tabular}{cccccc}
\hline & n & Min Value & Max Value & Average & SD \\
\hline Student Project Test & 30 & 70.28 & 85.74 & 80.50 & 4.47 \\
\hline
\end{tabular}

From the learning tools with the ADDIE model at the analysis stage, it can be concluded that it is necessary to develop learning tools with a project-based learning approach. The design stage includes designing syllabi, lesson plans, modules, job sheets, light engine maintenance learning modules for class XI, and also compiling assessment instruments. At the development stage, the design of the learning tools was developed. The validation was conducted by one material expert and one media expert lecturer, namely three light vehicle engineering teachers, so the total number of validator was five people, which consist of two expert lecturers and three light vehicle engineering teachers. The implementation phase is a stage where the learning tools/device is implemented and tested in the field.

The last stage is the evaluation. Evaluation was done by analyzing the data from the assessment of learning tools by expert lecturers and light vehicle engineering teachers. During the trial process, suggestions and input from teachers and students are accommodated to be used as improvements or revisions to researchers' learning tools.

The validity aspect seen from the syllabus assessment results is said to be feasible based on the validity aspect with valid criteria, and the average percentage of validator scores is $90.25 \%$. The evaluation aspect of the learning implementation plan is said to be feasible based on the validity aspect with valid criteria, and the average percentage of validator scores is $88.78 \%$. The learning module assessment aspect is said to be feasible based on the validity aspect with valid criteria, and the average percentage of validator scores is $86.56 \%$. The worksheet's assessment aspects are said to be feasible based on the aspects of validity with valid criteria, and the average percentage of validator scores is $88.93 \%$. The student learning achievement test instrument's assessment aspects are said to be feasible based on the validity aspect with valid criteria, and the average percentage score of the validator is $87.5 \%$. The assessment aspects of student project test instruments are feasible based on the aspects of validity with valid criteria. The average percentage score of the validator is $87.08 \%$. 
Syllabus assessment using the teacher response questionnaire received an average percentage score of $88.67 \%$ with very practical criteria. The assessment using the teacher's questionnaire responses got an average percentage score of $86.88 \%$. The learning module assessment using the teacher's response questionnaire received an average percentage score of $88.75 \%$ with very practical criteria. The worksheet's assessment using the teacher's response questionnaire received an average percentage score of $88.77 \%$ with very practical criteria. Assessment of test results based on teacher response scores received an average percentage score of $85.42 \%$ with practical criteria. The assessment of project test instruments based on teacher responses obtained an average percentage score of 83.33 with practical criteria.

Knowledge test results on 30 students and the project test scored a good average, but there are still four students who are under due diligence. However, the percentage of mastery learning classical in the class XI light vehicle engineering knowledge class at SMKN 1 Lahat is $86.67 \%$, and the skill field or project of the light vehicle engineering XI class is $86.67 \%$, it can be concluded that the learning tools are used effectively.

Of the three aspects of the assessment of learning tools above are aspects of validity, aspects of practicality, and effectiveness, all three are above the minimum assessment. Based on these results, the researchers concluded that the learning tools based on the project-based learning developed had met valid, practical, and effective criteria.

Using a project-based learning approach, the learning process in the classroom environment will increase in a better direction. This is in line with the statement of Arantes do Amaral and Lino dos Santos (2018) that the project approach enhances learning. Working together in a group environment is a pleasant experience in project learning (Arantes do Amaral \& Lino dos Santos, 2018). Students will both learn to solve problems in a different perspective. Findings like this are also similar to Arantes do Amaral et al. (2015), who report that project-based learning has a contribution in increasing students' knowledge and competencies. Students will be motivated, which is the positive impact of project-based learning (Arantes do Amaral et al., 2015).

Another finding is that project-based learning will help teachers in the learning process so that the focus of learning can be shifted to students, in line with the theory proposed by Baghoussi (2019) that using project-based learning will shift learning theories initially focused on the teacher to be student-centered. The module can be used well if it has passed the stages of validity, practicality, and effectiveness of use (Apriliana \& Warju, 2013). This is in line with the findings of a research that the learning tools developed are in accordance with aspects of validity, practicality, and effectiveness. The high response questionnaire for module practicality has proven that the module is suitable for use (Faridah \& Warju, 2014). The use of job sheets when practicum activities will improve student learning outcomes. This is in line with Abdillah (2013) thought that the job sheet has an important role in improving student learning outcomes in practicum activities. Project-based learning by developing job sheets allows students to learn independently in practical activities (Widyastuti \& Utami, 2018). Learning outcomes obtained are already at very high criteria with the application of this learning. Student learning outcomes will improve with the application of projectbased learning models, both cognitive, affective, and psychomotor aspects of students (Febriana, 2017). This learning activity will make students able to work independently and in groups or teams (Zancul et al., 2017). Learning activities in vocational schools will produce learning in accordance with the vocational received; successful students will bring the same skills as those obtained in a vocational environment (Prosser \& Quigley, 1950). The knowledge gained will be given proportionally because what is obtained is a real learning activity by producing a real product.

\section{CONCLUSION}

A project-based learning tool has been produced on the subject of light vehicle engine maintenance using the ADDIE development model. Learning tools that have been developed consist of the syllabus, lesson plans, modules, job sheets, test instruments for cognitive assessment results, and skills assessment instruments developed in accordance with valid criteria, practical and effective criteria. The test of learning outcomes and project tests on the criteria is very high based on the classical completeness aspects, with a percentage of completeness of $86.67 \%$ for each test. 
Learning tools developed will be very good to be applied when the learning process takes place. Learning tools that have been developed will bring students interested and make students understand the material because it is packaged according to student characteristics. The existence of a project approach will make students accustomed to solving problems, making time allocation of learning, solving solutions, and producing products. Project-based learning can be applied to vocational high schools in general. This can be done because essentially, teachers can develop project-based learning not focused on one agency or one school alone, which can involve vocational schools or other high schools.

Similar research activities develop project-based learning and develop learning tools in vocational schools and other public schools. Improvement of learning tools that have been developed can be redesigned in accordance with the needs of the characteristics of students. The development of this learning tool is not limited to one competency standard, but can be done on other competencies. Similarly, the implementation of learning that prioritizes practicum with the direction of developing students' vocational skills.

\section{REFERENCES}

Abdillah, M. A. (2013). Kelengkapan job sheet dalam meningkatkan hasil belajar mata pelajaran kelistrikan otomotif pada siswa. Gardan, 3(1), 1-10.

Abdul, M. (2009). Perencanaan Pembelajaran. PT. Remaja Rosda Karya.

Anjaya, P. D., Susilaningsih, E., \& Yulianto, A. (2019). Development of assessment instruments for learning process of mathematics in drawing geometry at the elementary school level of Karanganyar Regency. Journal of Primary Education, 8(3), 309-314.

Apriliana, F., \& Warju, W. (2013). Pengembangan modul Engine Tuner EA-800A pada mata kuliah praktek Motor Bensin di Jurusan Pendidikan Teknik Mesin Fakultas Teknik Universitas Negeri Surabaya. JPTM, 01(02).

Arantes do Amaral, J. A., Gonçalves, P., \& Hess, A. (2015). Creating a project-based learning environment to improve project management skills of graduate students. Journal of Problem Based Learning in Higher Education, 3(2), 120-130.

Arantes do Amaral, J. A., \& Lino dos Santos, R. J. R. (2018). Combining project-based learning and community-based research in a Research Methodology course: The lessons learned. International Journal of Instruction, 11(1), 47-60. https://doi.org/10.12973/iji.2018.1114a

Arends, R. I. (2001). Exploring teaching: An introduction to education. Mc Graw-Hill Companies.

Aydın, S., Atalay, T. D., \& Göksu, V. (2018). Project-based learning practices with secondary school students. International Online Journal of Educational Sciences, 10(3), 230-242. https://doi.org/10.15345/iojes.2018.03.015

Baghoussi, M., \& El Ouchdi, I. Z. (2019). The implementation of the project-based learning approach in the Algerian EFL context: Curriculum designers' expectations and teachers' obstacles. Arab World English Journal, 10(1), 271-282. https://doi.org/10.24093/awej/ vol10no1.23

Chiang, C. L., \& Lee, H. (2016). The effect of project-based learning on learning motivation and problem-solving ability of vocational high school students. International Journal of Information and Education Technology, 6(9), 709-712. https://doi.org/10.7763/IJIET.2016. V6.779

Damayanti, N. K. A., Martha, I. N., \& Gunatama, G. (2014). Pembelajaran menulis teks anekdot berpendekatan saintifik dengan model pembelajaran berbasis proyek (project based learning) pada siswa kelas X Tata Kecantikan Kulit 1 di SMK Negeri 2 Singaraja. Jurnal Pendidikan Bahasa dan Sastra Indonesia Undiksha, 2(1), 1-10. http://dx.doi.org/10.23887/jjpbs.v2i1. 3283 
Dick, W., Carey, L., \& Carey, J. O. (2015). The systematic design of instruction (8th ed.). University of South Florida.

Faridah, W. N., \& Warju, W. (2014). Pengembangan modul pembelajaran Injector Tester dan Ultrasonic Cleaner CNC-601A pada mata kuliah Praktik Motor Bensin Program Studi S-1 Pendidikan Teknik Mesin. JPTM, 02(03), 58-66.

Fatkhurrokhman, M., Permata, E., Ekawati, R., \& Rizal, S. U. (2017). Pengembangan perangkat pembelajaran teknik digital berbasis project based learning di Jurusan Pendidikan Teknik Elektro. Jurnal Pendidikan Vokasi, 7(1), 101. https://doi.org/10.21831/jpv.v7i1.12547

Febriana, R. (2017). The effectiveness of project based learning on students' social attitude and learning outcomes. Jurnal Pendidikan Teknologi Dan Kejuruan, 23(4), 374-382. https:// doi.org/10.21831/jptk.v23i4.14878

Gerhana, M. T. C., Mardiyana, M., \& Pramudya, I. (2017). The effectiveness of project based learning in trigonometry. Journal of Physics: Conference Series, 1-6. https://doi.org/ $10.1088 / 1742-6596 / 895 / 1 / 012027$

Habók, A., \& Nagy, J. (2016). In-service teachers' perceptions of project-based learning. SpringerPlus, 5(83), 1-14. https://doi.org/10.1186/s40064-016-1725-4

Hamid, M. A., Aribowo, D., \& Desmira, D. (2017). Development of learning modules of basic electronics-based problem solving in Vocational Secondary School. Jurnal Pendidikan Vokasi, 7(2), 149. https://doi.org/10.21831/jpv.v7i2.12986

Handoyo, L. D., \& Listyarini, I. Y. (2018). Development of character assessment instruments in service-learning at Biology Education Department Sanata Dharma University. International Journal of Indonesian Education and Teaching, 2(1), 71-79. https://doi.org/10.24071/ijiet. 2018.020108

Harmer, N., \& Stokes, A. (2014). The benefits and challenges of project-based learning: A review of the literature. Pedagogic Research Institute and Observatory (PedRIO).

Hoesny, M. U. (2013). From syllabus design to curriculum development. Jurnal Linguistik Terapan, 3(1), 1-10.

Ismuwardani, Z., Nuryatin, A., \& Doyin, M. (2019). Implementation of project based learning model to increased creativity and self-reliance of students on poetry writing skills. Journal of Primary Education, 8(1), 51-58. https://doi.org/10.15294 /jpe.v8i1.25229

Jaime, A., Blanco, J. M., Dominguez, C., Sanchez, A., Heras, J., \& Usandizaga, I. (2016). Spiral and project-based learning with peer assessment in a Computer Science Project Management Course. Journal of Science Education and Technology, 25(3), 439-449.

Jumargo, J., Boenasir, B., \& Ramelan, R. (2011). Peningkatan prestasi belajar kompetensi melakukan pekerjaan dengan mesin bubut menggunakan jobsheet hasil pengembangan. Jurnal Pendidikan Teknik Mesin, 11(02), 57-62.

Kricsfalusy, V., George, C., \& Reed, M. G. (2018). Integrating problem- and project-based learning opportunities: Assessing outcomes of a field course in environment and sustainability. Environmental Education Research, 24(4), 593-610. https://doi.org/10.1080/ 13504622.2016.1269874

Kunandar, K. (2013). Penilaian autentik (Penilaian hasil belajar peserta didik berdasarkan Kurikulum 2013. Grafindo Persada.

Martiningsih, I., \& Susilowati, S. M. E. (2019). Development of module based on scientific contextual additives material to increase learning outcomes and science process skills in junior high school. Journal of Innovative Science Education, 8(2), 128-137. https://doi.org/ 10.15294/JISE.V0I0.27790 
Mauliana, M., Ikhsan, M., \& Subianto, M. (2018). Development of learning tool with contextual teaching and learning (CTL) approach to improve student mathematical connection ability. Journal of Physics: Conference Series, 1-5. https://doi.org/10.1088/1742-6596/1088/1/ 012012

Mozas, A., \& Barba-Colmenero, F. (2013). System for evaluating groups when applying projectbased learning to surveying engineering education. Journal of Professional Issues in Engineering Education and Practice, 139(4), 317-324. https://doi.org/10.1061/(ASCE) EI.1943-5541.0000160

Muslim, M., Martias, M., \& Nasir, M. (2019). Correlation of activities learning with learning outcomes student in vocational high school. VANOS Journal of Mechanical Engineering Education, 4(2), 45-56. http://dx.doi.org/10.30870/vanos.v4i2.6349

Nurhasanah, A., Subekti, S., \& Patriasih, R. (2017). Analisis penggunaan jobsheet pada praktikum dasar boga di SMKN 9 Bandung. Media Pendidikan, Gizi dan Kuliner, 6(2), 1-8.

Prasetyo, Z. K. (2011). Pengembangan perangkat pembelajaran Sains terpadu untuk meningkatkan kognitif, keterampilan proses, kreativitas serta menerapkan konsep ilmiah peserta didik SMP. Universitas Negeri Yogyakarta.

Prosser, C. A., \& Quigley, T. H. E. (1950). Vocational education in a democracy (Revised ed.). American Technical Society.

Purnamasari, V., \& Wangid, M. N. (2016). Pengembangan perangkat pembelajaran berbasis scientific aproach untuk membangun karakter kepedulian dan kedisiplinan. Jurnal Pendidikan Karakter, 6(2), 167-180. https://doi.org/10.21831/jpk.v6i2.12047

Rusman, R. (2012). Belajar dan pembelajaran berbasis komputer: Mengembangkan profesionalisme guru abad 21. Alfabeta.

Sabbah, S. S. (2018). English language syllabuses: Definition, types, design, and selection. Arab World English Journal, 9(2), 127-142. https://doi.org/10.24093/awej/vol9no2.9

Sailin, S. N., \& Mahmor, N. A. (2018). Improving student teachers' digital pedagogy through meaningful learning activities. Malaysian Journal of Learning and Instruction, 15(2), 143 173. https://doi.org/10.32890/mjli2018.15.2.7786.

Sari, B. K. (2017). Desain pembelajaran model ADDIE dan implementasiinya dengan teknik Jigsaw. Desain Pembelajaran di era ASEAN Economic Community (AEC) untuk Pendidikan Indonesia Berkemajuan, 87-102. http://eprints.umsida.ac.id/332/

Sari, V. P. E., \& Mukhadis, A. (2017). The effect of problem-based learning with gallery project and locus of control on learning achievement. Jurnal Pendidikan Teknologi Dan Kejuruan, 23(4), 392-401. https://doi.org/10.21831/jptk.v23i4.14713

Serevina, V., Sunaryo, S., Raihanati, R., Astra, I. M., \& Sari, I. J. (2018). Development of emodule based on problem based learning (PBL) on heat and temperature to improve student's science process skill. The Turkish Online Journal of Educational Technology, 17(3), 26-36.

Shin, M.-H. (2018). Effects of project-based learning on students' motivation and self-efficacy. English Teaching, 73(1), 95-114. https://doi.org/10.15858/engtea.73.1.201803.95

Shofwanthoni, A., Ridlo, S., \& Elmubarok, Z. (2019). The development of authentic assessment instrument of Hajj Manasik practices of IX grade of SMP PGRI 10 Candi in Sidoarjo Regency. Journal of Educational Research and Evaluation, 8(1), 14-21. https://doi.org/ 10.15294/JERE.V8I1.28361

Soivan, S., \& Rijanto, T. (2018). Pengembangan job sheet trainer Human Machine Interface (HMI) sebagai bahan ajar siswa pada mata pelajaran Instalasi Motor Listrik di SMK Negeri 3 Surabaya. Jurnal Pendidikan Teknik Elektro, 07(02), 159-165. 
Sugiyono, S. (2017). Metode penelitian pendidikan (Pendekatan kuantitatif, kualitatif dan $R \& D$ ). Alfabeta.

Suhadi, S. (2007). Petunjuk perangkat pembelajaran. Universitas Muhammadiyah.

Syarif, M. (2016). Strategi pembelajaran. Rajawali Pers.

Trianto, T. (2014). Model-Model pembelajaran inovatif berorientasi konstruktivistik. Prestasi Pustaka.

Wahyuni, V., Kartono, K., \& Susiloningsih, E. (2018). Development of project assessment instruments to assess mathematical problem solving skills on a project-based learning. Journal of Educational Research and Evaluation, 7(2), 147-153.

Wekesa, N. W., \& Ongunya, R. O. (2016). Project based learning on students' performance in the concept of classification of organisms among secondary schools in Kenya. Journal of Education and Practice, 7(16), 25-31.

Widyastuti, R., \& Utami, I. S. (2018). Development of product-based job sheet as instructional media in vocational education. Journal of Educational Science and Technology (EST), 4(2), 119. https://doi.org/10.26858/est.v4i2.6064

Wiliam, D. (2013). Assessment: The bridge between teaching and learning (Vol. 21). National Council of Teachers of English. www.dylanwiliam.net

Winatha, K. R., \& Abubakar, M. M. (2018). The usage effectivity of project-based interactive emodule in improving students' achievement. Jurnal Pendidikan Teknologi Dan Kejuruan, 24(2), 198-202. https://doi.org/10.21831/jptk.v24i2.20001

Yulaelawati, E. (2004). Kurikulum dan pembelajaran. Pakar Raya.

Zancul, E. de S., Sousa-Zomer, T. T., \& Cauchick-Miguel, P. A. (2017). Project-based learning approach: Improvements of an undergraduate course in new product development. Production, 27(spe), 1-14. https://doi.org/10.1590/0103-6513.225216 